\title{
JUNGLE I.D.: EDUCATIONAL REFORM INSIDE THE BRAZILIAN PARAMILITARY POLICE
}

\author{
Eduardo Paes Machado* \\ Carlos Linhares de Albuquerque**
}

* Professor of the Department of Sociology and Institute for Public Health at the Federal University of Bahia, Brazil.

**Professor of the Department of Human Sciences at the Salvador'United Faculty.

\begin{abstract}
The article draws on direct observation and interviews with 27 of a total class of 70, in the Military Training Camp of the Military Police (Policia Militar), of the State of Bahia, Brazil. This activity is conducted in a secluded area of the jungle and has great psychological repercussions for both trainers and trainees. Through the sacrifice, humiliation, and pain imposed on the recruits, a team of 25 instructors consolidates the rite of passage from the condition of common civilian to that of Officer of the Military Police. Each year the Military Training Camp causes great damage to its victims, compounding its notoriety for brutal and dangerous training. Under the pretext of physical and psychological conditioning, the candidates learn anti-guerilla military techniques rather than methods of policing. We argue that such training is incompatible with the police reform, and that it contradicts and undermines the democratization agenda of the new instructional program of the Police Academy. The study advocates the elimination of this paramilitary training and related practices, so as to change the Military Police culture and effect the reforms supposedly already underway in the Brazilian Police Forces. The study also concludes that the overcoming of this resistance is beyond the scope of the reform of police education, depending on broader changes to guarantee the consolidation of citizenship and democratization of policing.
\end{abstract}

Key Words: Paramilitary police, educational reform, institutional resistance, social changes. 


\section{INTRODUCTION}

This article examines the reform within Brazilian police education, focusing on the approaches assumed by the political-institutional and cultural resistance to the new curriculums and training implemented in the police academies.

This reform which was initiated at the end of the 1980s, and accelerated in the 1990s, was inspired by international guidance, has raised issues that have been studied by researchers from several countries.

The studies into the reform of police education show that, despite the fact that certain advances were made, it has had less impact on police practice than was expected (Oakley, 1990; Post-Gary, 1992; Bryett, 1992; Wortley et al. 1995; Christie, Petrie and Timmins, 1996; Marion, 1998; Burger, 1998; Palmiotto, Birzer and Prabha 2000; Kempa, 2000; Chan, 2001). Confirming former findings on police socialization (Van Maanen, 1987), these studies showed that the reality principle, represented by the police profession and organization, undermine the idea of instilling the recruits with the principle of minimal force, human rights, tolerance, and social response appropriate to the situations encountered (Marks 1999; Chan 2001).

Amidst the vast literature on the theme, we underline the study carried out by Marks (1999), on the limitations of the training in promoting change in the postcolonial paramilitary police, aiming at replacing reactive positions based on excessive use of force with preventive and consensual methods.

Although the study does not go deeply into the discussion on the complex connections between security policies and educational practices, it was concluded that the failures of traning reform were a result of the lack of political will to implement changes in the South African Police Force (Marks, 1999). Given the overall lack of reliability on the new instructional principles, intermediary leaders, instructors, and police recruits regressed to what felt secure to them, the old lessons of the paramilitary police, placing excessive value on physical and tactical training and rejecting the consequences of this for the intensification of conflict and excessive use of force (Marks, 1999; Jefferson, 1990; Sheptycki, 1999; Waddington, 1999; Kraska, 1999).

Agreeing with the conclusions of Marks, this article discusses the education of high-ranking officers of the Policia Militar (Military Police Corps - henceforth, MP), examining the relationship between instructional methods and militarism as an ideology which stresses aggression, and the use of excessive force and military power as the means to solve problems (Kraska, 1996).

We focus on the Military Training Camp (henceforth, MTC), an ensemble of training and ritual which, together with other rituals - hazing upon entry, appearance leveling, (short hair cut and uniform), training - mark the transition from ordinary civilians to their new role as officers in the MP (Van Gennep, 1978; Riviere, 1996) . The MTC reveals the tension in the Bahian police of today, between what is supposed to be, and what is actually applied in the current implementation of a new curriculum created by police reform (Linhares de Alburquerque, 1999). 
We attempt to indentify the ambivalence of MTC since, though presented as one simple activity, it does assume significant proportions as a transmitter of professional identity - indeed, in a deeper way, qualitatively speaking, than the classes which make up the new curriculum. If the reformist tendencies are reflected in the new curriculum, loyalty to the militarist values is effected through rituals, myths, and stories of the institutional culture (Shearing and Ericson, 1984), as those which impregnate the MTC.

Thus, the current study formulates the notion of a counter-curriculum to explain the conjunction between the lack of political will and academic resistance to principles of reformulation of paramilitary police education. This counter-curriculum reveals the fragmented and contradictory characteristics of the new curriculum, filling it educational vacuums and asserting the "last word" of the police orgaization with regard to the proposed reforms.

\section{THE FIELDWORK}

This ethnographic study is based on long-term participatory observation carried out over three years, with partially pre-structured interviews with 27 students from the MP Academy of Bahia, out of a total class of 70 students who participed in a MTC, in 1997. The data gathered through these interviews was collated for analysis with other data gathered by the researchers in their roles as consultants and instructors at the MPA. This study eventually prompted the removal of one of the researchers from teaching at the MPA.

The interviews were conducted in the weeks following the return of the students from the MTC. The researchers were aware of the need for patience and flexibility so as to facilitate the objective identification of individual and group processes. In consonance with the psycho-analytic tradition, which considers silence as significant as other forms of expression, we were able to observe the psycho-social dynamics which lead the interviewees to be silent and to omit certain information as to the meaning of their recent experience, and we undertook to interpret the subjective dimensions of this complex drama.

Fear took hold of the candidates - fear of speaking, of exposing themselves, and simply of remembering in spoken word the situations which occurred during the training. Any attempt at dialogue conflicted with the code of self-censure at the core of the MTC initiation. The students raised a barrier of hostility, bordering on aggression, against the researcher's curiosity, and perceived him as one who intrudes in other people's affairs, without offering some tangible improvement in their lives.

Once this phase was overcome, after a moment of collective catharsis, marked by a cacophonous surging of voices and expressions, a new phase began, as the students agreed to fill out an interview form. This act facilitated alleviation of the reigning 
anxiety, allowing, for the first time, the broaching of a discussion at the Military Police Academy on the significance of the MTC.

The amount of obtained evidence confirms that the recruits are able to, despite how dependent they may be on the tactics of socialization in the police academy, develop criticism concerning police education, identifying ideological incongruities and operational impasses (Chan, 2001). This critical vision, however, does not deny the fact that they, as we will show ahead, need, in order to insert themselves in the organization, to make commitments and manifest adhesion to the dominating culture of the police force (Chan, 2001), or of the paramilitary police.

\section{THE BRAZILIAN PARAMILITARY POLICE}

Police force goes back to Brazil as a colony and during the period of slavery where, apart from existing private policing carried out in the sugar plantations by overseers or country captains, there was public policing to assist the troops responsible for territorial defense.

Such a type of policing persisted until the first decade of the 19th century, when the first specialized police force was created: The General Superintendency of the Police and The Royal Guards of the Police, the former having been inspired in the French institution Lieutenant General de Police (Tavares dos Santos, 1997; Bretas, 1997).

By means of these two police forces, the state began to provide instruments of control, which before this were entrusted only to the land-owners and their private agents, in order to repress and exclude the segments which received little or nothing of the benefits guaranteed for the ruling minority (Holloway, 1997). This system began to fulfill new functions in a changing socioeconomic context, maintaining, however, a reasonable continuity regarding structure and procedure (Holloway, 1997).

Created for the purpose of patrolling the streets, the Royal Guard was substituted, in 1831, by the Military Police, conceived as the Armed Forces of the Police of Rio de Janeiro, then capital of the Empire, and model for similar organizations in the rest of the country (Mattoso, 1992; Holloway, 1997). From its beginning, the Military Police applied punishment and employed policing techniques, such as humiliations, threats, and physical aggressions, which reinforced public hostility against it (Mattoso, 1992; Holloway, 1997).

The Republic, proclaimed in 1889, contributed to the improvement of qualification and in making the police a little less subject to the game of political influence (Bretas, 1997). Amid these advances, the police reaffirmed clientelistic relationships with the elite in power, who tolerated the police violence and corruption as long as they were 
only being directed towards the popular classes. The expectation of the elite was that public order be maintained, no matter what methods were used by the policemen, reputed, by them, as being uncontrollable and inferior (Bretas, 1997).

With the Revolution of 1930 the power of the local private authorities was reduced, and the first police academies were founded. The Civil (or Judiciary) Police, in turn, was refashioned to act as a secret political police force against political adversaries of the dictatorial regime Getulio Vargas.

This legacy prevailed in the following decades, when new authoritarian impulses, such as the 1964 coup d'état, prioritized the ideology of the cold war and the fight against the domestic allies of international socialism and communism. For this reason, the policemen began to be trained in anti-guerrilla techniques by qualified instructors from North American military academies. The police forces were armed with machine guns, developing coordinated actions among themselves and with the armed forces, to watch, arrest, extract information, and to eliminate members of political organizations considered subversive.

It was also a time in which the death squads, which initially arose in Sao Paulo, in the Civil Police Force, at the end of the 1950s, in order to execute delinquents, began to integrate the repression of political opponents of the government, intensifying the elimination of suspects and eventually becoming an important link to organized crime in the 1980s (Barcelos, 2001; Mingardi, 1991).

During the transition from a military to a civilian regime, from 1979 to 1985 , the congressional lobby of the military police obstructed (as it continues to obstruct) reforms by members of parliament who feared being accused of retaliation against the authoritarian regime, and thus kept the old police model intact.

The Military and Civilian Police Forces (from now on referred to as CP), act within the limits and under the administration of the 26 states of the Union. The MP (with 345,487 officers) and the CP (67,525 officers) have differentiated responsabilities of preventive and investigative policing, which, in the majority of modern police forces, are gathered into a single organization. The consequences of this fragmentation of activities, called police dualism (Soares 2000), go beyond the traditional rivalry among police departments, increasing the competition for scarce resources, limited communication and impeding joint decision-making.

Both police forces nominally are accountable to the state governments, under specific secretariats. However, only the $\mathrm{CP}$ is effectively subordinate to the state governments, given that the MP is under their administration and at the same time under the control and coordination of the federal government, and, in particular, the armed forces (Bayley, 1985). 
Though a subversion of federative principle (Soares, 2000), the juridical statute of the MP, as an auxiliary force to the Army, guarantees the power of the latter over the civilian political institutions, restricting the authority of the states and reducing accountability (Lemos-Nelson, 2001).

In copying the military model of organization, the MP characterizes itself by the concentration of decisions, inflexibility of communication, and standardization of procedures, giving more value to internal discipline than to end product of the policing (Guimaraes, 2000; Soares, 2000). Although the police reform in the 1990s has reduced the number of ranks, the MP maintains a super-centralized standard which conditions the base of the pyramid to adopt passive behavior (Guimaraes, 2000).

Among the models of conduct, that of the police hero or super-hero, embodied in courageous men, capable of committing aggressive and violent acts against delinquents (and suspects), is mostly valued (Guimaraes, 2000). That dominant model, prevalent across Brazilian society, prioritizes emotions, producing amateur and harmful actions, with unexpected results and unnecessary consequences, for policeman as well as for other involved persons (Guimaraes).

The power of this conception also permeates the performance evaluations and the results of inquiries, resulting in the tolerance and approval of misconduct, among which executions stand out (Chevigny, 1995; Hugguins, 2000; Cano, 1997; Cedec, 1997; Lemos-Nelson, 2001; Paes Machado and Noronha 2002).

The MP own academies and training programs, which work on the circumstances in which the policemen can use force or firearms, but the lack of standardized procedures on the subject, favors a variety of interpretations, many times guided by individual values or standing corporatives.

The influence of militarism and warrior mentality (Kraska, 1996; Franke, 2000) is expressed in what little importance is given to the transmission of negotiation (disescalation) techniques of conflicts, and moderate use of the so-called intermediary resources of force. In addition to this, silhouette models for shooting are used in training, give priority to the lethal parts of the human body, not emphasizing the importance of preserving the lives of the suspects.

The almost complete lack of weapons and ammunition constitutes a serious obstacle for the shooting training, causing the policemen not to acquire proficiency (Linhares de Albuquerque, 1999), and making them a threat to public safety when obliged to shoot.

In general, the reform of police teaching, aimed at compatibility with the new legal code, was restricted to general theoretical lines, without modifying operational methods. It did not overcome resistance to the modification of police procedures so as 
to reduce the disproportional use of force (Paes Machado, Noronha and Cardoso, 1997).

\section{THE MILITARY POLICE ACADEMY OF BAHIA}

The initial training of high-ranking police officers of the Bahian MP takes place within the walls of the Military Compound, situated at Bonfim, in Salvador, in the section known as the Military Police Academy (Academia da Policia Militar, henceforth, MPA), a large area, full of stories and traditions. Approximately 280 students finish the Academy each year. Before a person can join the MPA and obtain a full scholarship for four years, (s)he must take a competitive service examination. These young men and women, aged between 18 and 24, with the exception of a few older aspirants, are oriented by about 40 professors and instructors, both civilian and military.

The new official curriculum of the MPA was established between 1992 and 1994, as part of a modernization policy developed in collaboration with the Federal University of Bahia, and international consultants. The launching of the new program was marked by the rising of the fear of crime and the military occupation of the largest shanty-town in South America, the Rocinha, in Rio de Janeiro, to repress the drug traffic. Influenced by these events, the MP of Bahia decided to implement police reforms which were already being developed in other Brazilian states since the late 1980s.

With the introduction of the new curriculum, the duration of the training of the future high-ranking police officers went from three to four consecutive years of classes, from March to November, with a one week break in June. In comparison, the training of the future low-ranking police officers takes only 6 months and is conducted in precarious conditions, which, by MP regulations, does not permit promotion to the rank of Corporate Officer (Dornbusch, 1955; Paes Machado, Noronha and Cardoso, 1997). This lack of promotional opportunities is at the base of the strong sense of resentment of low-ranking against high-ranking police officers - a sentiment which undermines hierarchical respect and can lead to police strikes which can precipitate calamitous situations of public insecurity, such as the strike and simultaneous massive looting and violence which occurred in July of 2001 in Salvador, as well in other cities of the state of Bahia.

The officer-candidates are exposed to the content and strategies of a revamped curriculum which is based on five major disciplinary areas: i) administration and organization; ii) juridical procedures; iii) physical education and sports; iv) specific police subjects; v) humanities and Portuguese. In addition to theses subjects, there is a cluster of highly valued extra-curricular activities, including, most notably, running, cleaning, and walking. There are also sports championships, civic celebrations, various internships in different units of the MP, and other experiences which take 
place outside the physical space of the Academy, such as the MTC, which is part of the formal curriculum, but whose contents are not disclosed to the public.

The recruits are largely from the lower middle class and from suburbs close to the MPA, which are not greatly valued in real estate terms. These youths often come to the MPA with the ambition of social betterment, which would otherwise be inaccessible given that their families do not have financial resources to pay for private education, a virtual necessity for success in the admission exams to the coveted public universities (in Brazil, more prestigious and of more academic rigor than most private institutions).

More than $85 \%$ of the entering class of 1994, for example, were from families in which neither of the parents had a university degree. It is rare to find a young middleclass white with parents who have a university education. Poor whites from rural areas are in a comparable situation to that of the blacks and dark-skinned persons from the capital, and find themselves vulnerable to the socializing processes of the institution (May, 1997). The presence of a large number of non-white recruits suggests, however, that among major local public organs the police corps remains a particularly important space for upward social mobility.

A small but significant portion of the recruits are the children of MP officers. These recruits proceed through training with a special attitude, since they have the privilege of understanding certain subtle points in the prevailing institutional ethos. They are aware that the desired social advancement does not come automatically merely from the official training process, technical knowledge of the profession, and so on. They know that to be successful it will be necessary to grasp that the police hierarchy reproduces that of the military, and is not a simple structure of individuals and levels, but, rather, is a question of cliques and power groups. They will have to find a "fish" for themselves (peixe - literally, a"fish", but here a slang term within the institution denoting a friendly patron, a powerful protector). Managing entry into one of these circles of alliance will assure that one is "fished" - this complementary term is widely used within the MPA, and associates career success to the practice of patronage.

\section{THE JUNGLE TRAINING}

The MTC consists of an immersion experience for the MPA recruits in a stretch of native forest along the Atlantic coast, not far from Salvador, belonging to the Brazilian Army. About 70 candidates, from the second year of the Academy, spend 6 days under the supervision of 25 instructors (10 high-ranking and 15 low-ranking police officers), i.e. with fewer than 3 candidates per instructor, engaged in an activity which will have na enormous impact on their lives forever. Far from the home-base of the Academy, lodged in tents, they will undergo situations generating extreme frustration.

Similar to the traditional training methods, which combine jungle survival techniques with anti-guerrilla techniques from the days of the struggle by the military 
dictatorship (1964-1985), against political organizations considered subversive, the MTC is carried out at a stressful pace, based on tactics which provoke anxiety and fear, producing a psychological state of absolute emotional limit.

Secrecy surrounds the accounts of the camp. Whoever goes there never knows in advance exactly what awaits. Incredible stories are heard before departure, feeding the candidates' fearful apprehension. Given all the mystery and terrible stories, the recruits naturally suspect that it will not be just another extra-curricular training course. Each year new stories are circulated about excesses which are said to have occurred at the MTC during the previous year, causing great harm to the victims.

Maintaining its basic characteristic as intensive military training, the MTC presents stylistic variations according to the pragmatic decisions of the instructors who act as intermediaries between the MPA officer class, the students, and the on-site pressures in the field, in the jungle (Willis, 1977). Within these limits, the only rule of thumb, here, seems to be to avoid rules in general, in the sense that they would make operations repetitive or predictable. One could even imagine the MTC being converted into a new species of "radical sport", for general consumption, by daring young consumers; the only difference would be that it would lose its "rite of passage" initiation aspect.

The MTC begins with a bus trip from the Academy to the site of the camp. The trip is stressful and painful, with simulations of assaults and gas bombs inside the bus. The trip lasts about one hour. After the arrival and gathering of all persons for presentation to the camp leaders, the rules are stated.

The immediate task, upon arrival, is the preparation of the camp, (tents, kitchen, definition of areas to be used as "bathrooms," etc.), and a march around the grounds. In the mornings, after reveille, instructions on the day's activities are passed out, following which a meager breakfast is consumed.

In the jungle camp, there are two types of days: (a) days for tests and military games, in which the candidate has to surpass his/her natural limits, displaying courage and "esprit de corps"; (b) days oriented around competitive games which set one individual against the other, in a warlike setting, using guerilla techniques. In order to foment this, the group is divided into two sub-groups which become opponents in a continuous belligerent confrontation. The young men and women, thus, undergo a didactic simulation of hostility, with a series of practices designed to terrorize them.

In this simulation there are defined strategies, and arms are used with blank ammunition. The losers are called abatidos - those "cut down" or, literally, "butchered." They pay later with exercises, sacrifices, and public punishment. This mixed context of war-zone and survival tests, fosters a group spirit which is only produced in certain realms of a contemporary individualist society, and which involves collective fervor, the abandonment of the self, or the dilution of individual 
identity in a larger mass, which temporarily takes over personal responsibility. This gregarious spirit is, in turn, at the root of what we will examine ahead as "jungle fraternity".

The pauses for meals, rest, and personal hygiene depend on the program of the day. Recruits who have suffered accidents and injury can be temporarily relieved from activities.

At the end of each day, the exhausted recruits must still settle their score with the Leadership Team (Goffman, 1996), paying what they owe in punishments, exercises, and listening to sermons delivered in the form of yelling. The exchange for this payment is corporal suffering and sacrifice. These payments, nevertheless, have a didactic function - the acts of torture are public ceremonies. Sleep then overcomes the trainees and affords a brief moment of respite. A new day awaits the warriors with an ever greater load of stress, and reduced sensibility and critical sense. Thus, the training course is infamous for its harshness and stressfulness, reinforcing the symbolical ties between the MP and the Armed Forces (Linhares de Alburquerque, 1999).

\section{A RITE OF MILITARIZATION}

The MTC affords a strong and personal encounter for the officer-candidate with a synthesis of the MP identity. This identity is celebrated in the middle of the forest, a mythical place in fact. Just as for the recruits of the regular Brazilian Army, the highest praise among the MPA candidates is to be called a "jungle-man" (selvatico "of the jungle"). One will yell to another the exclamation "Jungle!" (E selva - "It's jungle!"), meaning that the "jungle-man" has exceeded all limits and proven himself a warrior.

The term "jungle" entered the army imagination due to the symbolic importance of affirming Brazilian possession and defense of the Amazon, a sacred element in Brazilian national identity, and one supposedly threatened by the specter of foreign invasion (Leirner, 1997: 28). The army cadets are versed in Amazon emblems, possibly as a sort of alternative to the imagery of Icarus used in the Air Force, and that of white swans used in the Navy.

In this sense, the identity of each branch of the armed forces contains a basic element of nature: earth (for the Army), water (for the Navy), and air (for the Air Force). Each element is linked to a characteristic attitude in the respective military branch (Castro, 1990). The jungle-men of the Army are the zealous guards of national borders and trail around the jungles. The sailors are men who travel from port to port, prepared to deal with different peoples and cultures, and wear white, which represents diplomacy. The Air Force men are high-tech, precise, and mathematical, using sophisticated and expensive machines, passing through the heavens. And the Military Police? What is its characteristic attitude, its symbolic mythology? 
Taking the army as a reference of identification (Waldman, 1996), the MP adopts its symbolic repertoire to express its own role as a public organ, addressing principally the issue of the security of the State (national security), rather than protect the citizens, in a process of institutional mingling between the police and the military institutions (Baremblitt, 1980). This mingling occurs when the cultural core of one penetrates another, modifying the corporational genetic coding and the character of the officers for instance, when the police force as a corporation is penetrated by the military logic of eliminating the enemy (Waddington, 1999).

Whether it be that the recruits come from a civilian domain, or that they were influenced to some degree by the modernization of the agenda, the majority of officercandidates think that the MTC is not appropriate to police spirit, because, after all, it is not a real police activity (Tavares dos Santos, 1997), but rather one whose methodology is based on militarism. This is indicated in the words of one of the interviewees, Rodrigo (20 years old):

Where am I going to find a vine and a river to cross in the city? This mania for mixing army things in with police matters is a pain in the ass ... we waste time in the jungle, getting beaten up and dying of hunger.

For some, the training in the forest deliberately confuses police and military objectives. They question whether the procedure makes sense for persons who are going to work in cities. In trying to answer this question, an informant, Angelo (20), offered the following explanation:

Perhaps the training in the forest fits in with military life, (army, navy, air-force), but it isn't a useful sort of training for MP officers; it was practically useless given that the police, today, are a citizens' police. I don't feel myself more "military" than before the camp; it was just a physical and emotional endurance test. But, the MP doesn't have its own culture, or rather, the MP has a culture which thinks its an army culture.

The basic error of the MTC, for this and other interviewees, lies in the militarized emphasis on its procedures, which contradicts the welcome speeches which are made in the classroom and associated with the creation of a Community Police. As it was stated by Selma (19):

The omnipresent militarization of the MTC ties your head in knots, it's confusing ... a trip ... because it seems like you are about to be in a war, it seems like you are going to go out and hunt terrorists like back in the days of the dictatorship. The confusion is because during the two years at the Academy we hear a lot of pretty talk by the professors about how the new police spirit is about creating a different relationship with the community - all that stuff, and then all of a sudden the citizen police thing disappears in the six days of the camp. 
The same sort of assessment was made by Andrea (22), who asserted that the MP must not take the perspective of the armed forces, but rather seek a relationship with the citizens who need its services:

(...) because yelling, torturing, throwing gas, and washing in contaminated water are not going to be passed on to the population we will work for. The MP does not need this sort of contact, it needs a relationship with society, with social issues, because that is what it is going to work with. The military part is for the army.

The MTC appears to solve the narcissistic identity issue of the MP, colliding head on with the new curriculum in the process. Which of the two will prevail? The democratic ideology of the new curriculum is currently losing ground to the militarist mentality, as is clear in the way the scenarios created at the camp suppress the rights of the individual. From this emerges a sort of enemy-mentality, where the thirst of the martial spirit is quenched only by war, where there are communists and subversives everywhere. And if, as of the end of the military dictatorship, there are no longer any, there is still a general curse on the working poor and on young black and dark-skinned (mulatto), males (Paes Machado, Noronha and Cardoso, 1997), who become a perpetual suspect, a bandit or delinquent, or - to use the most common slang word in Brazilian Portuguese for a criminal, a "marginal".

In the other hand, the MTC experience commemorates, even with the women recruits, a phallic man, dominator of himself and superior to females. A pure man, virile and untouchable, as the environment found in a jungle, which contrasts with the post-modern man: fragile, possessing no insignia, and manipulated. In other words, the paramilitary celebration confirms historico-cultural standards of behavior which remount to a mythic time, where there existed a hegemony of male leaders, and phallocentrism was related to the conquest (and maintenance) of the national territory.

\section{THE SACRALIZATION OF HIERARCHY}

Though the student may have worked on the theme of leadership in administration and psychology classes, what will his/her notion of leadership be after the MTC? In the testimony gathered, there is no account of any scene where the figure of a consensual leader, coordinating processes, using democratic management methods, is evoked, though these are all features of the new curriculum.

The candidates, and also some officers, who consider that the MTC is an antiguerrilla warfare festival, accuse it of promoting an outmoded method of policing. In this respect, the students make a series of criticisms of the behavior and attitudes of the instructors during the training:

They show little psychological maturity regarding such a heavy emotional experience ... they show a lack of ability to deal ... this 
comes through in the abuses and arbitrary things - they get revenge for old resentments (Denilson, 21).

Their actions lack any transparency, they don't communicate (Jeferson, 22).

They try to get at the psyche of the students, apart from requiring the physical conditioning (...) disappointment with the instructors for their use of "the way" (...) little or no professionalism for a mission like that (Carolina, 21).

They are arbitrary, like masked MP officers, truly unjust (Raul, 22).

Under the orders of these officers, the students personally experience the negative stereotypes of the police, held by the poor masses (Paes Machado, Noronha and Cardoso, 1997). They undergo that which common citizens undergo when they are beaten and pushed in the Brazilian criminal justice cycle. They feel what it is like not to have anyone to defend them from the arbitrariness of hierarchical superiors.

For an external observer, disgusted by the spectacle of this regressive explosion of crude impulses (Freud, 1977), it is not reasonable to think that society should have to fund this sort of training for its future administrative guards.

Why should there be such a degree of theatrical violence? Why do the instructors become, without censure, the very embodiment of arbitrariness and sadism? One answer to this was given by Elias who described how the training of German duelist group members combined the expression of barbaric impulses with the learning of rigid codes of obedience, as one means of imposing the learning of the code of conduct of the German military-bureaucratic elite (1997: 94-95).

This consideration consolidates the interpretation that the rigorous teaching of the MTC is that the use of police force consolidates in a big hierarchical pyramid, which is reproduced in the relation between the paramilitary police officers and the intimidated citizens (Freire Costa, 1994: 13).

\section{THE ART OF “THE WAY”}

"The way" is an inside term for learning within the MP - learning achieved through sacrifice, humiliation, and pain. It is a part of daily practice at the Academy, but it appears in a more dramatic manner at the MTC.

Like the classic Brazilian practice of "finding a way", (jeitinho brasileiro - finding a way around a rule or dilemma, considered a national trait), which subverts the rigor of rules and fosters conceptual flexibility and laxity (Barbosa, 1992: 18), "the way" condenses this ambivalence toward a blind (disinterested and fair), justice system, and the tendency toward being arbitrary, through its oscillation between instruction and sadistic outbursts, and the transmission of a unbalanced and aggressive identity. From 
any of these various points of consideration, "the way" must be seen as a corruption of notions of both systematic rules and decent personal limits.

The Leadership Team at the camp, which teaches law defense, is the same one which breaks the common law and, thus, imposes another law, one which is conceived as greater. "The way" becomes legal (and plausible), because it goes beyond the regular law in its cognitive and rational dimension. Like bluffing in poker, "the way" breaks in, like a lying game, a "con", but, a clever, legitimizing one, appropriate within this particular game.

"The way" begins at the MTC when the recruits get on the bus which takes them to the jungle. Called upon to participate, they find themselves in the role of combatants, enlisted in a fight which they do not understand, nor do they wish to be involved in. Thus, for Samuel (22), the instruction begins:

(...) when we are at Bonfim, at the Academy, being pushed into a bus by the common police soldier; on the way we are forced to travel on the floor of the bus, with the windows blinded, and everyone crouching so as not to be seen by the enemy outside.

Apart from maintenance tasks at the camp, the candidates "pay" dues in the form of exhausting physical exercises, in a constant state of silent suspense. Thus, according to Joel (22):

The worst part was the continual atmosphere of suspense, the silence during the training activities, and the painful surprises, and all of a sudden getting a dose of "the way" from Lieutenant X ... or seeing him brutalize someone else.

Complete masters of the situation, the instructors concentrate their anger on various individuals who, turned into scapegoats, are beaten and ostracized, even getting their tent pulled down for the pleasure of the instructors. According to the recollection of the scene by Bernardo (20):

It was horrible to see the sheer arbitrariness of the instructors, who take advantage of the situation, to take out personal dislikes on certain students ... or to hear soldiers and sergeants receiving orders to beat certain students more than others - the ones the instructor didn't like - or to see an instructor pushing a student down into the metal tubes holding up the tent without giving a damn about the fact that the student could be seriously injured, or to witness the lieutenants beating a student on the helmet so much that his head was hurt and he passed out.

According to the degree of acceptance or resistance, the severity of "the way" is greater against those who, for various reasons, rebel against the abuses. Thus, within the context of unquestionability which surrounds the training (Dornbusch, 1955), the instructors increase the dosage of punishment to those who resist. This is also noted by the informant Bernardo (previously mentioned), who said: 
The questioning type of student was punished - denied meals or having to "pay" by doing physical exercises while still going hungry... the students received different treatment from the instructors, who indulged personal preferences.

As with military academies, where it is taught that formalized rules and procedures are not always more important than informal rules, and where a differentiated treatment of individual transgressors of discipline is possible (Dornbusch, 1955), at the MTC, punishments are applied, according to the status of the transgressors, or the personal preferences of their superiors.

If one reflects on the experience of "the way" by certain recruits, it is impossible to determine where rationality ends and sadism begins in treating the trainees. As a psychological trait of masculine groups or ones dominated by male-chauvenist notions, sadism is a sensation of pleasure stimulated by the suffering of another, which features, not merely the victim of the painful action, but, also the conscious witness of the power over the other. The recognition by the victim of the power over the latter is more important than moans and tears; it is a question of reducing the victim to the point of abolishing him/her as an autonomous subject. This victory must be loudly articulated by the oppressor; the sadist needs to see that (s)he is being seen. What empowers him/her is not the brutal force used to bring the other down, crushed under his army boots, or whipped, but the acquiescence of the victim, submerged in pain and sacrifice.

The testimony of the interviewees suggests perplexity on their part and refers to their shock in encountering procedures charged with arbitrariness and brutality. Their eyes - fearful without their realizing it - fed the sadist appetite and reveals the key lesson here: in facing the power of a military police officer, there is no cry or tear which will move him/her to pity.

The sadist component emerges in the relation between the officer-instructor and the recruit, with the latter made into an object of tyranny and the terrorized witness of the aggression of an arbitrary power, embodied in the person who recreates the student as a warrior, who generates his/her identity.

The daily routine in the MTC reveals another regressive trait, also violent and arbitrary. Through the testimony of Lea (20), we know that:

The way the tasks are conducted, without any real sense, completely irrational, with us being obliged to lie in the hot sand in strong sunlight, and so on (...) After the instruction on the sequence of action and reaction, it was a festival of sadism, an absurd series of punishments, it was the law of the fist, and some of the instructors and monitors took advantage of the situation to "show the way" to (punish) the students. 
"The way" is part of the rite of passage and fulfills the purpose of diluting previous identity (Dornbusch, 1955; Janowitz, 1964; Van Maanen, 1978; Franke, 2000). One must wash the soul of the remains from the old civilian condition. The soap for this washing is simply pain, sacrifice. The new curriculum principles which are still in the mind of the cadet will be shipwrecked in the forest.

\section{THE SEARCH FOR EFFICIENCY}

Amongst the most pernicious stigmas for the officer-candidates are the terms "inoperative" and "inefficiency." The implementation of the reform of the MP of Bahia, together with the Federal University of Bahia, undertook to work on these issues, promoting improvements and making the question of efficiency one of the key topics in the academic realm.

Motivated by pragmatism, the students pressure for practical application of the teaching offered in the Academy, including activities such as the MTC. Questioned on this point, the 27 candidates, divided between a few who agreed in part, and the majority, who completely disagreed with the notion of military instruction as a factor improving police efficiency. For those who partially accept the jungle camp training, its major advantage is that it puts them in a situation related to what they will encounter in their future work. This was the view of Joseval (22):

I think the instructors understand that we finish the Academy still very under-prepared, and they want to give us a little taste of reality through the MTC simulation.

Another informant who tried to reconcile the old and new curricula, Olivia (22), thought that the police training cannot be restricted to only one of the two modalities:

(...) neither through the boring lessons [in the Academy] at

Bonfim only, nor just through the running around and humiliation of the MTC.

This student affirmed that the paramilitary training tries to communicate what the concrete reality would be, in opposition to the idealized picture of society presented in the theoretical classes of the MPA. Similar to the South African (Marks, 1999) and Australian (Chan, 2001) recruits, the Brazilian recruits question the generic character and, for them, the small amount of practicity of the renewed curriculum, expressing a liking for the physical and tactical contents contained in the MTC.

A conflict between the two curricula is implied here: the new curriculum would prepare them for an abstract institution and to serve in an imaginary social collective; the old curriculum of the MTC, by comparison, would prepare them to work in a violent and savage society, which really does exist. 
Disagreeing completely with this training as a means of increasing efficiency, Leandro (22), reiterated the sense of revolt against physical aggressions used as a pedagogical method:

In the session on "action and reaction", for example, one instructor kept hitting the same student in the head, on his helmet, and as he was hitting him he kept yelling that he was there teaching the student to be a man. Do you become a man through getting bashed?

In the same line of thought, Clovis (22), notes that the going beyond the individual limits of the students does not make the teachings of the MTC more useful or adequate for police work:

The camp had gone beyond what we could take and had become a useless experience, marked by the direction of disoriented instructors, psychologically ill-prepared, rehearsing rural guerilla tactics for future officers who will work in urban centers with a different type of social pressure.

Adding to the chorus of those who judge the training to be improvised and brutal, Benedito (22), observes that efficiency depends on planned action, something not incorporated into the military instruction:

This [need for planning] was not communicated in the general hubbub of the camp, in the ambience of irrationality and of great physical stress, which did not permit the notion of efficiency to prevail, but rather that of brutal force, improvisation, and hoping to get a break, good luck, in moments of desperation.

It would seem that the only planned event is the intention of pushing the trainees to their physical and emotional limits, and to this end the system of orientation for the trainees is deliberately scrambled by the issuance of mutually contradictory orders. According to Edilson (23):

An instructor ordered a dick to go to the river, another ordered him into the forest, and another ordered him to go sleep. The dicks ended up doing different things and then being even more punished and confused.

In contrast with this focus, the best police training, according to Benedito, flows from a cultural change, from the development of values and attitudes to deal with the public, something which contrasts with the posture of disrespect adopted by the camp instructors in relation to the students, the police officers of the future:

If efficiency is the product of a better public security, one more civilized and which respects the common citizens, this will depend much more on the firmness of my values and comments than on the MTC, where the instructors gave us a show in how to disrespect. 
For Clara (20), who came back from the paramilitary instruction with one of her legs in a cast, the training contributed little to the process of education in the profession, because of the lack of specific technical content and, above all, organization:

We learned from some of the instructions, (such as those on how to approach a suspect and how to shoot), but they added nothing in terms of efficiency with the parts on chemical agents, patrols, containing crowds, impeding bus hold-ups ... and there was plenty of time, but it was lost, under-used, because the instructors are more concerned with their "way", (hassling, punishing), than with teaching. From my point of view, efficiency is related to objectives, and the MTC does not succeed in transmitting the notion of efficiency because it is a mess.

While denying the positive contribution of paramilitary police training for professional competence, this testimony, like many others, confirms the success of the camp as a rite of passage. The leg in a cast provides a concrete translation of the abstract meaning of this ritual. The efficiency of the training in the jungle takes place at the symbolic level of marking inclusion in the paramilitary police world.

\section{THE MARKING OF BODIES}

Reproducing practices of transmitting cultural codes through the provocation of physical pain (Clastres, 1990), the instructors seek to inscribe the content of training on the bodies of the initiates. The cycle of exercises, thus, includes the acquisition of a mark (or wound), on the body, which registers the fury of the rite of transmission of identity, as was observed by Santiago (21), commenting on the wounds of his colleagues at the military training:

Many of the people in this room right now are wrapped in clothes, not because it is cold, but, rather because they received a wound at the MTC and are hiding the mark.

Invested with the magical status of a priest, the instructor initiates the neophytes in the dimensions of paramilitary police identity through rituals. The Leadership Team in the jungle takes the role of a precinctless police force, and teaches how to reproduce the model of a police force against the citizens. We could identify in this contradiction a schizophrenic trait in a corporation whose mission is to defend-guard-serve-protect, and which, however, if one simply takes a look at the crime page in any newspaper, actually does the opposite of this promised role.

It must already be clear that the real point of the MTC is to make the apprentice perceive that the warrior identity comes before police identity. We suspect, therefore, that the paramilitary instruction inflicts pain on the body with an intention of 
punishing democratic institutions, by a process of symbolic transferal. We consider that the disguised torture applied in the military training attacks the power of these institutions, cutting the polis with incisions in the skin of the apprentice, who is initiated in a law for which there is no appeal.

It did happen this way for the young man, Silas (21), who was thrown in the river in one of the exercises, and begged for mercy because he couldn't swim, and sunk into the dark waters and into the logic of the police game. Silas was pulled out, and with difficulty, was revived, vomiting water. Inexorably, this experience of near death awoke the jungle-warrior identity - he witnesses the nullification of democratized instruction. He is now submissive toward the law of the jungle, and, so, can return to the city. In the jungle, it would appear that excessive use of force becomes a course of order, something natural, generating extreme competition as the key to power relations. In this baptism of fire, it is to be supposed that Silas completed the passage, and subjectively emerged into the light of a forcefully constructed obedience.

\section{THE JUNGLE FRATERNITY}

Despite the notion that the MTC militarizes the police hierarchy through a complete verticalizing of the relation between officers and recruits, it is possible to discern the inverse of this aspect in certain situations, where the best result will be obtained by relying on one's brothers in uniform, and where the only way out will be an effort for group solidarity.

In the midst of the experience of one's identity being annihilated by the institution, there are scenes of reciprocal help, of the sharing of encouraging words, and group efforts to extrapolate some sense in the nonsense going on, to help a companion who is exhausted, humiliated, and beaten. The most emblematic scene of this tension between verticality and horizontality can be seen in the terrible punishment given to the recruit who decides to take on the pain being inflicted on another, and intervenes in the beating of a fellow trainee by an officer, for example. The moral of the story is, "you will get the same punishment as the person you dared to defend, but with twice the intensity." The would-be savior must learn and teach others that there is an additional cost to this fraternity, a price to be paid with one's own body.

In this jungle school, solidarity between equals can never be seen as the act of a sissy, let alone a good or charitable action, but rather a coherent attitude in a situation of formation of a group of equals. In this search for, or offer of, help amongst one's fellows, it is not a question of moralizing or teaching, but rather a group strategy for sheer survival.

From this dynamic, group identity emerges inside the institution, which in itself recognizes the troupe as belonging to a particular generation or fraternity, determined by the year of entering the MPA, participation in the MTC, and graduation. The 
fraternity is valuable in the sense of making future officers identity their specific place in the institution, and avoiding dilution in an amorphous corporate mass with the theoretic title of "corporation." In other words, in unstated ideology inculcated in the paramilitary instruction and elsewhere, they must not inscribe themselves in an idealized and massive institution - the "MP" - or see themselves each as one more individual member of this extensive police organization, but, rather identify themselves as members of a particular fraternity of new officers, made up of personal names and familiar faces, officers who together survived the same rites of passage (Van Maanen, 1987).

Through the group-solidarity pact, they will conclude that such fraternity is very welcome, though it carries a heavy cost - one which will increase in cases of betrayal of group confidences.

Such fraternal ties are so strong that, outside the jungle, and where the obstacles are different, each member will be able to rely on his/her partners (Skolnick, 1966). By the same logic, the members of the fraternity will be able to quash regulations, and trample their own future inferiors, thus, reaffirming internal ties within their own class, and, further, counting on a shield of impunity when they go beyond the limits of the law.

In a further sense, the fraternity nurtured by the MTC can be seen as an ideological shock absorber in the conflict between meritocracy on the one hand, and, on the other, clientelism and other modalities based on differential treatment.

\section{COMPENSATION FOR THE TRAUMAS}

A pitiful bean stew picnic, to which are invited the parents of the students, commemorates the end of the camp, after six days of "pure hell", there in the jungle. The photographs of one student (Flavia, 21), showed images of this silent lunch, at which she appears downcast, apparently depressed, with her parents at her sides, the three of them with their heads bowed, facing the ground. They are in a rough wooden structure showing the greeness of the jungle surrounding them. They are at a table of unpolished wood, dorned with party food. But, there is no party. What happened to them over those six intense days, that it seems impossible to celebrate together with their parents? What championship was held for which they have no desire of laurels or medals? Why doesn't even the presence of their parents relieve them from looking like they have just seen something horrifying?

For some, the jungle was a successful occasion to demonstrate abilities, see the failure of others, and increase their self-esteem in conjunction with identification in their new role (Dornbusch, 1955) of "jungle-man". The return required a new social paradigm on their part - in the light of their experiences, a review of the web of personal relations. 
Some blacks, for example, found in the struggles of the jungle, a chance to outperform their white colleagues, who usually have better grades in academic classes. Women who outperform their male colleagues, bring away a different set of lessons from the odyssey of the military training. One black female student outdid her colleagues in one of the more difficult MTC tasks, including colleagues who were "macho racists and who never treated me the same way again" (Tania, 21).

In the same way, some students who have influential relatives in the corporation were spared hardship, by differential treatment and the "law of the fish" mentioned earlier, but this became more obvious at the paramilitary instruction, or, in the words of Eleandro (21) "more shocking." The visibility of such unfair interventions led to the undermining of the prestige of these students for succeeding in various areas, and they returned humiliated.

Such interpretations testify to the effort of the students to compensate for frustration, annihilation, and pain with the notion of merit through sacrifice. In contrast with the resistance displayed by pupils in government schools in the U.K., who prefer to break with the school system rather than accept its authority, curricula, and pedagogy (Willis, 1977), the resistance of the Brazilian MPA recruits, even the most critical, end up justifying the jungle practices as a complex result of the students' social project of betterment, dissatisfaction with the generic character of the new curriculum, and survival tactics in the organization (Chan, 2001).

\section{CONCLUSION}

The MTC is one of a range of psycho-social experiences conducted by the MP force, which promotes esprit de corps through the mortification of personal identity. It is developed, as we have seen, within a zone of space and time marked by the density of signifiers and the intensity of contents, as well as by a phenomenology of violence inflicted and inscribed on the bodies of the officer-candidates.

The agendas encountered at the MTC can be opposed to the proposals in the new official curriculum, just as, in some cases, they may complement them. They are opposed because the police corporation itself refuses to believe in the capacity of a new curriculum to form officials in its own likeness. They can complement the new proposals because they qualify and deepen notions of this image, reinforcing militarist aspects which the formal curriculum do not foster. In any case, what is at stake is always the unquestionability of the militarized image of the police officer, and the need to feed into this image.

The MTC is a means to de-legitimize the authority of the modernization theme promoted in academic reform, and constitutes nothing less than a counter-curriculum, intent on sabotaging the new official discourse, and undermining implementation of reformed methods in police training. Like a torrential river, this counter-curriculum produces an effective stream which pushes the changes of everyday academic life to the glorious past, an ocean of narcissistic certainties, a mythical time of 
unquestionable force, where the waters reflected police identification with the armed forces, militarism, and warrior mentality.

The military training camp, however, provokes ambivalent reactions by the students, oscillating between condemnation and approval.

The predominant command of the paramilitary police instruction, according to one of the dissenting voices, is this: "he who has power can do anything." Thus, the violent posture, which the new official curriculum camouflages in democratic discourse, is clearly affirmed by ritual: the policeman, so it would seem to read in the police book of Genesis, is "born under punches."

At the other extreme of this ambivalence, the candidates end up realizing that the MTC paradigm actually translates, with precision, the militarist culture of the organization they hope to part of. This paradigm depends on the cultivation of the warrior ready to show aggressiveness, and the use of excessive force and military power as the means to solve problems.

Furthermore, the recruit takes on board the lesson that he dare not assimilate the social control of a democratic society because, given the authoritarian heritage and terrible inequities, such a society remains a merely utopian prospect. He bears with him a clear idea that the rigorously ritualistic curriculum contains terms of action which can control the real social subjects one encounters both within and outside the police force. They learn that a little violence can compensate a citizen's sense of personal insecurity.

The Police Academy adopt a twisted logic which is surmount to perversion. They teach the knowledge of the reformed curriculum, which guarantees a good contemporary image of the moderate policeman, while conserving roots in the mythical landscape, where the police continues its cruel stereotype, of exaggerated use of force, certain of exercising a paternal function in society (Stenning, 2001; Gabaldón, 1996; Lévy, 2001).

Given this, any criticism could promote a new sense of memory, and warn the police that their fathers' era has changed, that the social network operates better as a fraternal function (Lévy, 2001) and cause the Corporation to question what type of father figure can exist in a democracy. It's important to remember that a democracy is the dynamics of a social situation moved by the unfamiliarity of still having a father, a father who is so omnipresent and controlling. The criticism will be able to stimulate the operators of public security to conceive another model of paternal authority, and become a partner in taking over this imaginary fortress.

With the current circumstances of external and internal pressures for the reform of police forces, it is necessary that they not only reformulate their instructional programs, as has already been done in Bahia and other Brazilian states, but, also change their deeper institutional and cultural values. The organizations will therefore have to overcome internal resistance which, using the pretext that there is a risk of discharacterization, sabotage the democratization agenda. 
The overcoming of this resistance, however, is beyond the scope of the reform of the police education implemented to this date, depending on broader changes to guarantee the consolidation of citizenship and democratization of policing.

\section{REFERENCES}

Baremblitt, G. (1998) Introducao a esquizoanalise. Belo Horizonte: Instituto Felix Guattari.

Barbosa, L. (1992) O jeitinho brasileiro; a arte de ser mais igual que os outros. Rio de Janeiro: Campus.

Barcellos, C. (2001) Rota 66: a historia da policia que mata. São Paulo: Globo.

Bayley, D.H. (1985) Patterns of policing: a comparative international analysis. Rutgers University Press. pp. 23-52.

Bretas, M. L. (1997) Ordem na cidade: o exercicio cotidiano da autoridade policial no Rio de Janeiro, 1907-1930. Rio de Janeiro: Rocco.

Bryett, K. (1992) Police recruit preparation in Australia. Canadian Police College Journal, 16(3), pp.175-183.

Buerger, M. E. (1998) Police training as a Pentecost: using tools singularly ill-suited to the purpose of reform. Police Quaterly, 1(1), pp. 27-63.

Cano, I. (1997) The use of lethal force by police in Rio de Janeiro. Rio de Janeiro: Instituto de Estudos da Religiao.

Castro, C. (1990) O espirito militar; um estudo antropologico na Academia militar das Agulhas Negras. Rio de Janeiro: Jorge Zahar Editor.

Cedec. (1997) Mapa de risco da violencia de Salvador. Sao Paulo: Cedec. 
Chan, J. (2001) Negotiating the field: new observations on the making of police officers. Australian and New Zealand Journal of Criminology. V. 34 ,i 2. pp. 14-133.

Chevigny, P. (1995) The edge of the knife: police violence in the Americas. New York: New York Press.

Christie, G., Petrie, S. and Timmins, P. (1996) The effet of police education, training and socialisation on conservative attitudes". Australian and New Zealand Journal of Criminology, 29(3), pp. 299-314.

Clastres, P. (1990) A sociedade contra o Estado. Rio de Janeiro: Francisco Alves.

Dornbusch, S. M. (1955). The military academy as an assimilating institution. Social Forces 33, pp. 316-321.

Elias, N. (1997) Os alemaes: a luta pelo poder e a evolucao do habitus nos seculos XIX e XX. Rio de Janeiro: Jorge Zahar Editor.

Foucault, M. (1984) Microfisica do poder. Rio de Janeiro: Ed. Graal.

Franke, V. C. (2000) Duty, honor, country: the social identity of West Point cadet. Armed Forces \& Society: An Interdisciplinary Journal, v. 26 i2 pp.175.

Freire Costa, J. (1996) Violencia e psicanalise. Rio de Janeiro: Ed. Graal.

Freud, S. (1977) As pulsoes e seus destinos. Standard Edition. Vol. XIV, Rio de Janeiro: Imago.

Gabaldón, L. G. (1996) La policia y el uso de la fuerza fisica en Venezuela.” In: P. Waldman (ed.)Justicia en la calle; ensayos sobre la policia en America Latina. Medellin: Biblioteca Jurídica, pp.269-281.

Goffman, E. (1996) Manicomios, prisoes e conventos. Sao Paulo: Editora Perspectiva.

Guimaraes. L. A B. (2000) Valores institucionais: a pratica policial militar e a cidadania. Unidade - Revista de Assuntos Tecnicos da Policia Militar. Ano XVIII, n. 41, jan./mar., pp. 45-85. 
Holloway, T. H. (1997). Policia no Rio de Janeiro: repressao e resistencia numa cidade no seculo XIX. Rio de Janeiro: Fundacao Getulio Vargas.

Huggins, M.K. (2000) Urban violence and police privatization in Brazil: blended invisibility. Social Justice, v. 27,n. 2, pp.113-134.

Janowitz, M. (1964). The military in the political development of new nations. Chicago and London. The Univ. of Chicago Press.

Jefferson, T. (1990) The case against paramilitary policing. Milton Keynes: Open University Press.

Kempa, M. (2000) Thinking about political reform through the prism of policing: A review essay of Les Johnston's Policing Britain: Risk, Security and Governance. Policing and Society, vol 10, pp. 301-316.

Kraska, P. (1996) Enjoying militarism, Justice Quarterly, vol.13, n. 3, September. pp. 405-429.

Kraska, P. (1999) Questioning the militarization of U.S. police: critical versus advocacy scholarship. Policing and Society, vol. 9, pp.141-153.

Leirner, P. de C. (1997) Meia volta volver: um estudo antropologico sobre a hierarquia militar. Sao Paulo: FGV/FAPESP.

Lévy, A. (2001) Ciencias clinicas e organizacoes sociais; sentido e crise do sentido. Belo Horizonte: Autentica/Fumec.

Linhares de Alburquerque, C. F. (1999) Escola de bravos. cotidiano e curriculo em uma Academia de Policia Militar. Master Thesis, Universidade Federal da Bahia.

Lemos-Nelson, A T. (2001) Judiciary Police accountability for gron Human Rights violations: the case of Bahia, Brazil. Ph.D. diss., University of Notre Dame.

Marks, M. (1999). Changing dilemmas and the dilemmas of change: transforming the public order Police unit in Durban, Policing and Society, v. 9, pp. 157-179. 
Marion, N. (1998) Police academy training: are we teaching recruits what they need to know?. Policing, 21(1), pp.54-79.

Mattoso, K. (1992) Bahia, século XIX: uma provincia do Imperio. Rio de Janeiro: Nova Fronteira.

May, L. (1997) Socialization and institucional evil. In: L. May (ed.)Hannah Arendt; twenty years later. Cambridge: MIT Press, pp. 83-105.

Mingardi, G. (1991) Tiras, gansos e trutas: cotidiano e reforma na policia civil. Sao Paulo: Scritta.

Oakley, R. (1990) Police training in ethnic relations in Britain. Police-Sudies, 13, (2), pp. 47-56.

Paes Machado, E.; Noronha, C.V., and Cardoso, F. (1997). No olho do furacao: brutalidade policial, preconceito racial e controle da violencia em Salvador. Afro-Asia, 19/20, pp. 201-226.

Paes Machado, E.; Noronha, C. V. (2002) Forthcoming. A governanca do uso da forca policial no Brasil. Manuscript.

Palmiotto, M.J., Birze, M.L and Prabha, U.N. (2000) Training in ccmmunity policing: a suggested curriculum. Policing - An International Journal of Police Strategies and Management, 23, (1), pp. 8-21.

Post-Gary, M. (1992) Police recruits: training tomorrow's workforce. FBI - Law Enforcement Bulletin, 61, (3), pp. 19-24.

Rivière, C. (1996) Os ritos profanos. Petropolis: Vozes.

Shearing, C. and Ericson, R.V. (1984) Cultura as figurative action, British Journal of Sociology,n.42(4, december), pp.481-506.

Sheptycki, J. (1990) Editorial reflections on policing, "paramilitarisation and scholarship on policing. Policing and Society, Vol. 9, pp.117-123.

Skolnick, J. (1966) Justice without trial. New York: Free Press. 
Soares, L. E. (2000) Meu casaco de general: 500 dias no front da seguranca publica do Rio de Janeiro. Sao Paulo: Companhia das Letras.

Stenning, P.C. (2001) Forthcoming. Gouvernance of Police use of force in Canada. Manuscript.

Tavares dos Santos, J. V. (1997) A arma e a flor: formacao da organizacao policial, consenso e violencia. Tempo Social; Review of the School of Sociology, U.S.P., São Paulo, v. 9, n. 1 (maio), pp. 155-167.

Van Gennep, A. (1978) Os ritos de passagem. Petropolis: Vozes.

Van Maanen, J. (1987) Observations on the making of policemen. In Peter K. Manning and John Van Maanen(eds.) Policing: a view from the street. Santa Monica: Goodyear Publishing Company, pp. 292308.

Waddington, P. A.J. (1999) Swatting police paramilatarism: a comment on Kraska and Paulsen. Policing and Society, vol. 9, pp.125-140.

Waldman, P. (1996) Introduccion. In: P.Waldman (ed.) Justicia en la calle: ensayos sobre la policia en America Latina. Medellin: Biblioteca Juridica. pp. 17-27.

Willis, P. (1977) Learning to labor; how working classe kids get working class jobs. New York: Columbia University Press.

Wortley, R.K. and Homel-Ross, J. (1995) Police prejudice as a function of training and outgroup contact: a longitudinal investigation. Law and Human Behavior, 19(3), pp. 305-317. 